\title{
Research with children as theologians: Ethical and methodological issues
}

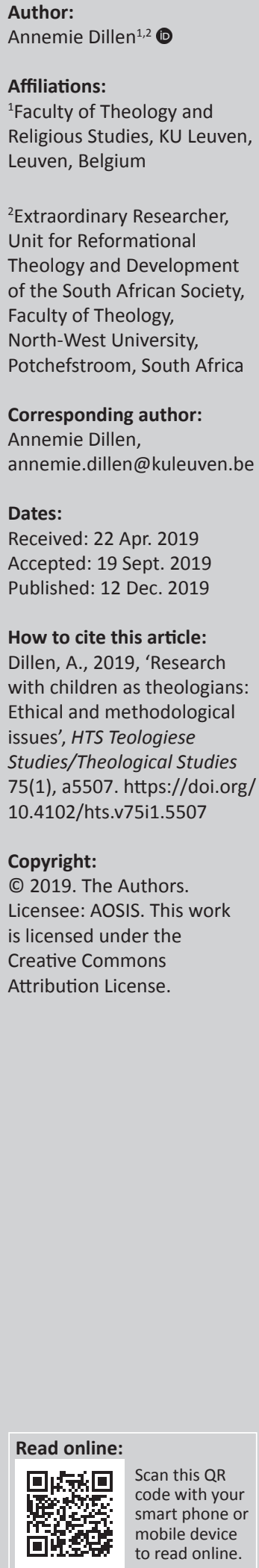

In this article, I explain why it is important for theologians to involve children in empirical research, and why children themselves can and should be considered as 'theologians'. Therefore, I refer to theories in childhood studies and child theology (children as active participants and subjects), and also to contemporary trends in empirical research and practical theology (views on theology and ethnography, lived religion etc.). Counter-arguments for involving children in empirical research are discussed as well. In the second step, I deal with ethical issues and discuss which aspects have to be taken into account when doing research with children.

Keywords: Childhood studies; Empirical research; Practical theology; Research ethics; Children's spirituality; Empirical theology.

\section{Introduction}

Since the beginning of the 21st century, many articles and books have been written on children and theology or children and spirituality, especially in German and English. Within the Germanspeaking context, the field of Kindertheologie (German field) has been developed, mainly in relation to religious education in schools, which is widespread within Austria, Switzerland and Germany (for an overview, see e.g. Zimmermann 2015:1-6).

Within the Anglo-Saxon world, the International Journal of Children's Spirituality and the related International Association for Children's Spirituality bear witness of the growing interest in children's own voices. Simultaneously, a growing body of literature discusses images of and practices with children from a theological perspective, including various sub-disciplines (church history, biblical studies, practical and systematic theology, theological ethics etc.). Various researchers acknowledge, in line with the broader 'childhood studies' in social and educational sciences, that children are active subjects whose rights (and duties) have to be taken seriously (see e.g. Miller-McLemore 2003; Wall 2004, 2010).

However, about 20 years of increasing research about 'children and theology' leave us with some tensions and questions. There are still lacunae in the field, and ambiguities and paradoxes have to be discussed.

The first part of this article deals with the ethical justification of 'research with children' and thus answer the following fundamental question: Why is research with children, who are considered as theologians, important? The second part handles the following question: How good practices in empirical research with children, as theologians, can take shape, taking into account ethical and methodological considerations?

\section{Research with children as theologians: Pros and cons}

In many countries, researchers experience resistance when they propose projects involving empirical research with children. Children are to be safeguarded against all forms of instrumentalisation or abuse. Nevertheless, there are very good reasons why theologians set up empirical research where children are involved and why they consider the children they are working with as theologians. I discuss three main positions from the perspective of contemporary practical theology and indicate each time which arguments could be given against these positions in favour of research with children.

\section{Emancipatory theologies}

Childhood studies have indicated that children should be considered more and more as 'active subjects' whose voices should be heard and taken seriously. This argument is based on a view of

Note: Doing Theology with Children: Exploring Emancipatory Methodologies, sub-edited by Stephan de Beer (UP Centre for Contextual Ministry) and Hannelie Yates (North-West University). 
children as more than 'not-yet-adults' on the one hand, and on an emancipatory position, which challenges classical power structures. Both elements need more explanation. Classical stage-theories, based on developmental psychology, are criticised because of the view that the last (adult) stage is often considered as normative, which reduces earlier stages and experiences in childhood to only preparatory stages. Theologians have considered Rahner's (1966) expression that childhood has a value for eternity as a support for this criticism (see e.g. Hinsdale 2001). Children are valuable as such, as is also clearly expressed in the Office of the United Nations Convention on the Rights of the Child (1989). They have their own dignity, which deserves special protection.

In line with the Convention on the Rights of the Child, various authors argue that children do not only have a right for protection and provision of fundamental goods (e.g. food, housing) but that they also have participation rights. They are not only vulnerable persons in need of education and socialisation, but they also have their own voice. Children are increasingly taken seriously in society, e.g. there are children's parliaments in cities or schools. In many other cases, their voices stay unheard and many of their rights are offended. Elsewhere, I have argued extensively how participation of children is very important, also from a theological point of view and especially also in the context of church. It is, however, good to consider this argumentation in light of broader movements and tendencies within theology and humanities.

Feminist authors and theologians have shown how important it is to listen to women and not only to speak about them. Within theology, it took a while before the voices of all kinds of women received more attention. In the earlier stages of feminist theology, it was mainly female scholars who would speak in favour of other women and claim more justice in society. Only recently, more empirical studies with women are being published within the domain of feminist theology (Slee 2004:44; Slee, Porter \& Phillips 2013, 2018). In this way, the voices of lay-women (here meaning 'non-expert' women) are taken more seriously as a theological source.

Postcolonial and decolonial theology are more recent developments within the theological discipline.

Authors identifying as postcolonial or decolonial theologians share with feminist theological approaches their concern for listening to the people themselves and not only speaking about them. Making power structures visible, empowering those who have been unheard and unseen for a very long time, is also common to all these approaches of theology. Postcolonial and decolonial theologians often focus on the voices of indigenous groups, theologians from the Global South or oppressed people anywhere in the world. The idea of 'empire' is analysed and criticised. Voices from the margins are questioning dominant ways of thinking.

Both feminist and postcolonial/decolonial theologies challenge male-stream/mainstream theologies to rethink what is considered as normative or normal and argue for real change of dominant discourses instead of asking 'other views/persons' to adapt in order to be included/seen. These authors come up with a 'radical theology' in its original meaning: It wants to tackle the 'radix' (root) of oppressive systems by challenging dominant ways of thinking in terms of 'centre' and 'margins'.

Taking children more seriously in theology and doing empirical research with children can be considered in line with both growing perspectives (feminist and postcolonial/ decolonial theology), although there are of course differences also. However, the major arguments are similar: children have to be heard and seen, we should listen to them and not only speak about them, not treat them as mere victims, vulnerable beings and not-yet-adults nor only argue in favour of them. Children are not passive objects but active subjects.

It is, however, good to consider differences between e.g. Kindertheologie (in the German field), or the empirical study of children's spirituality (Anglo-Saxon world) on one hand, and feminist/postcolonial/decolonial perspectives on the other hand. One of the major differences is the fact that children mostly become adults, and that their statute as children is a temporary one. This is different from women or oppressed, colonised groups of people in the world. Critical voices state then that children only have to wait until their voices are heard. One could come up with many critical arguments not only against doing empirical research with children but also against taking children's voices really seriously in didactical situations (e.g. classrooms) or in political decision-making. I enumerate at least five slightly different counter-arguments.

(1) One could ask whether children really have something specific to contribute as they are similar to adults, but only 'notyet-grown up' and thus in a 'waiting room' to really contribute. (2) According to Zimmersman (2018), others would say: 'Yes, but if we want to take children's voices seriously, this does not really offer us much material, as their answers are usually very short and fragmented'. Children's answers are not always considered as very coherent, sometimes they would be mixed up with fantasy elements, or it might happen that children do not really understand what the research questions are all about, or that they are just not interested. (3) In other contexts, critical researchers would say that the empirical research with children only confirms the prejudices of researchers; they interpret children's answers as they want, or they hear what they want to hear. (4) Some theologians might be hesitant to do research about children's own views, as they doubt the representativity of these results. Children are different, and how can you expect to say something about the own ideas of children if you know they might have very different opinions and experiences, according to their age and development, social-economic position, ethnicity and nationality, religious upbringing etc. (5) An argument that is valid for every form of empirical research, but especially for research with children, is the idea that children will mainly say what the adults want to hear. Owing to power differences between adults and children (Zimmerman 2018) and the educational contexts in which children are usually situated, many children are inclined to 
please the adult-researcher (often interviewer) and give answers that are 'acceptable' or can be considered as 'correct' from the perspective of adults. What the children are really thinking, their spontaneous answers or their real struggles might be unheard. They might also adapt to other children if they are interviewed in a group (focus group interviews) and answer 'yes, I think the same', to many questions.

One wonders then to which degree the research is valid, which means, telling us what the children really think and experience, and not just what is acceptable in a partly artificial research setting.

These are many critical questions which have to be taken seriously. Part of these criticisms can be tackled by an adequate and responsible research design, in which, for instance, researchers reflect on their own positions and presuppositions, in which the danger of giving socially acceptable answers might be avoided, as much as possible, or in which the participation in the research is made attractive to children and adapted to what they can understand and like (see also Zimmermann 2018). Other aspects of this criticism are applicable to other forms of empirical research as well, such as the question about the representativity and the diversity within the group of children. In order to tackle this critical remark, one can answer that this is the reason why a growing body of research is necessary, in which various contexts and groups of children are studied.

An answer to this critique, which is particularly developed within feminist theology, is the perspective of intersectionality. This is an approach which stimulates researchers to see differences between, for example, groups of women and take into account the various, intersecting axes of gender, ethnicity, social economic status, age, religion, etc. Such an intersectional approach, which also takes into account the power balances and the privileges related to certain positions, is needed for theological approaches in childhood studies as well. A white Catholic child, coming from a higher middle-class family, living in Belgium, might have other views than a Muslim child in Malawi, who lost his parents. This difference is evident, but also within the group of Catholic children in Flanders, even those in the same class in school, there might be differences. These varieties need to be reflected in the theological work. This does not prevent the possibility of doing research with children as theologians. The more difficult question which cannot be answered easily by choosing adequate research methods is whether doing research with children is worthwhile at all, whether children really have something to offer. The answer to this question depends on the image of children. There is plenty of literature arguing for newer concepts of children, as active subjects, living in a context and in relations with others. It is possible that one does not accept these positions but sticks to a more classical paradigm (e.g. children are first of all vulnerable beings, in need of protection and socialisation).

Another question which raises lots of debate concerns the idea of children as theologians. If scholars agree upon the relevance of setting up empirical research with children about their spirituality, they might have different views on the question whether children can be called 'theologians' (see also Dillen 2017). The German field of Kindertheologie refers directly to the term 'theology' as a name for children's reflections on religious issues, which are discussed in pieces of qualitative (and more rarely also quantitative) research.

Most of this research takes place in classroom-contexts and is set up by scholars in the field of didactics of religion. Within the German context, but also in my own context in Belgium, there are many children who do not consider themselves as believers. They might be explicitly atheist, or just not interested in religion, or they might be searching without clear commitment to a specific religion, or they might take another position.

Children with these various positions take part in classes of religious education, even if they are organised according to specific denominations (Catholic, Protestant, Islamic, religious education), as is often the case in Germany or Belgium. The basic discussion is then whether all expressions of children, in answer to interview questions about religion, might be called a form of 'theology' and whether these children can be considered as 'theologians'. A similar discussion takes place within the global field of theology and religious studies (see, e.g., Ganzevoort 2013; Nikitaki 2018). When children are called theologians, this means that they are taken seriously and that the idea of 'theology' is not limited to experts within church or academia or to explicit believers. Some would argue that this does not take into account the diversity within the group of children and that it over interprets children's perspectives, putting them into a group they might not really want to fit in, if they are not very familiar with or rather explicitly negative about religion. The title of this article, 'Research with children as theologians' refers to the double question: Why and how is research with children for theologians relevant, but also, are children themselves considered as 'theologians' in this empirical research? My answer to this question is 'yes' if we use a broad concept of theology (see also Dillen 2017). This broad concept is explained in the next part of this article.

\section{Research with children in line with the study of 'lived religion' and the many voices of theology}

The basic question so far was why empirical research with children (as theologians) is important. So far, the answer was: 'In order to listen to the own voices of children'. I have placed this question in line with other perspectives within theology (feminist theology, postcolonial/decolonial theology) and discussed possible counter-arguments. The second possible answer is that research with children is relevant to investigate the fluidity and diversity in ways in which religion or theology is experienced/interpreted. This argument is closely related to the research within the field of practical theology and religious study, especially to the researchers focusing on the 'study of lived religion'. 'Lived religion' is a concept which is popular for various practical theologians and scholars within the field of religious studies (for an overview, see Dillen 2016). Authors such as the sociologist of 
religion McGuire (2008) indicate that by studying 'lived religion' the focus on research is broadened, away from the focus on institutionalised religion towards all forms of religion as experienced in daily life by individuals and groups. The study of lived religion helps scholars to see that religion is not limited to classical religious practices such as attending church services or prayer life, and that various religious practices are 'blended' and 'merged' within the life of an individual or a particular group. This approach offers a critique of classical secularisation theories, which presume that religion is diminishing or might even disappear. 'There is more religion than you have been thinking so far', might be a catchy phrase of scholars studying lived religion. In the field of childhood studies, this means that dominant discourses in churches such as the idea that the next generations are less religious and that religious practices are declining, might be challenged or at least complemented by other results, based on the work with children. International studies with children have shown that many children experience spirituality in relation to their daily life practices (Hay \& Nye 2006).

One example is based on research in Belgium. In the Spring of 2018 Amy Casteel interviewed young adolescents who recently came to Belgium. Most indicated that their faith is quite important and that they had a religious practice at home. However, in Belgium, either they go infrequently to church or their parents do not attend anymore because the experience of church in Belgium is very different than what they are used to at home. What does this mean? Religion plays a role for many people with a migration history, but it does not fit into prescribed categories, it is experienced as 'outside the box'. Casteel describes how the migrant adolescents describe their faith in a rather conventional way, but they also explain how they experience their faith without real participation in an organised faith community (Casteel \& Dillen in press). This research results show obstacles in belonging to a community, and also show that studying the role of religion only from the perspective of a congregation or a religious institution and what it offers (or not) for children and adolescents, is limited.

Within religious studies and practical theology, the study of lived religion is widely held as important.

However, there are some restrictions formulated by various (groups of) scholars and 'ordinary people'. The idea that religion is something static, mainly characterised by institutionalised views, doctrines and rules exists generally in society - I speak here from my Belgian context - as well as being a belief of theologians.

In Casteel's pilot research, she experienced a surprising level of resistance from international schools where she asked to interview students about their spirituality. Many school chairpersons refused because they considered spirituality private similar to one's religious affiliation. In the media, the increased plurality of religion and spirituality because of growing migration is often framed as raising new problems, especially owing to conflicting ideas about gender equality and bodies. The idea that spirituality and religion are significant for many individuals or society as a whole is often neglected because the way this is lived is rarely noticed, much less how this relates to, for example, the capacity to cope or flourish. When religion is considered something static and institutionalised, the positive possibilities of lived religion or spirituality are often forgotten.

Within academic theology and church teachings, it is also not evident that lived religion is taken seriously. Existing paradigms, doctrines and models are often to be followed in relation to both content and methodology. Especially within Catholic practical theology - my own field -- the term lived religion is seldom used. Two possible explanations could be given. The German Catholic practical theologian Mette (2005:37-38) states that the term 'lived religion' might refer too strongly to individual experiences and neglect the social, ethical and ecclesial aspects of religions. Another explanation for this limited interest in the study of lived religion from a Catholic perspective could be the already high level of theological attention within Catholic theology and life to spirituality, practice and sacraments, which is probably more than in Protestant contexts where the explicit study of lived religion is something new and attractive. Within Catholic theology, there is traditionally a strong focus on sacramental theology, but there is, for example, very little research about how children themselves experience first communion. The work of Bales (2005) (herself a Protestant) about Catholic children and their experiences of first communion in various congregations in the USA, functions here as one of the few exceptions. Studies with children about their lived religion in relation to first communion might add to a more complex and diversified picture of children's own views and might stimulate church leaders to rethink possible prejudices and practices. In general, studies on lived religion do not focus very much on children's perspectives. Here is a whole field to explore and to deepen theories on lived religion as well.

The term 'lived religion' is used in reference to practices, rituals, experiences and specific theological views. Others prefer to use the term 'lived theology' (for a discussion on the variety in terminology, see Müller 2019). In both cases, the aim is to enrich classical forms of theology with views from 'lay (i.e. non-expert) persons', or what Astley (2013) calls, 'ordinary theologians'. Cameron and co-authors (2010) speak about the 'four voices' of theology and thus explain various ways of using the term 'theology'. They speak about formal theology or academic theology, next to normative theology as expressed by church documents, the Bible or other authoritative sources. Both voices are often considered as 'the theology', but there is much more. Cameron et al. (2010) speak about individuals' and group's operant and espoused theologies.

Operant theologies are seen in practices, such as showing hospitality for others, offering diaconal services, caring for others at home or showing gratitude to others and God. 
Espoused theologies are similar to what Astley calls 'ordinary theology' or what is considered as 'children's theologies' in reference to empirical research with children. These refer to the ways persons, here especially also children, think about religious issues. The term 'espoused' refers to the fact that persons, especially also children, do not live alone but borrow aspects of what is being thought by churches, what is expressed in society and taught in a more formal way in classrooms and congregations. They combine this with their own reflections and aspects they also learn from peers and thus come to their own 'espoused theologies'. This view clearly explains how studying children's theologies does not have to consider children in isolation (see the critical remarks of Schweitzer 2011).

Cameron and others (2010) argue that the task of academic theologians, particularly practical theologians, is to stimulate dialogue between these various voices of theology. It means of course that the various voices have to be seen and to be respected in their mutual relationships, which should not be dominated by only one voice. In practice, this is often very complex, but this dialogical view, referring to four voices, offers perspectives for a complex and diverse understanding of theology and religion.

Studying children's perspectives might also help to ground the dialogue between the various voices of theology in a more empirical, evidence-based way, adding evidence to experiences of teachers, catechists and other adults. The question is now how this dialogue between various voices should take place, and how the relationship between children's perspectives and what is classically considered as normative or formal theology could take place. It is more obvious for didactical perspectives or religious education in general.

Theories that take children's voices seriously, study their 'espoused and operant theology' or consider children's lived religion, might often be more dialogical, using a 'constructive view' on didactics, which is not top-down but offers room for children to bring in their own views. Learning processes are generally more student-centred. As I present it here, this seems evident, but an approach such as Godly Play, which takes children's own spirituality seriously, is also considered by some as too much teacher-centred (Müller 2007:99). Or in other words, where the relation between the attention for children's own views and didactical approaches seems not all too complex, we see in practice that scholarly debate is growing in this field as well (see also Dillen \& Hendrickx 2018; Grajczonek \& Truasheim 2015). The discussion about the relation between theological theories and children's theology/lived religion cannot be discussed here extensively (for further elaboration, see Dillen 2016). Basically, it depends from the view on theology, as more static, with a focus on divine revelation, or as more inductively fed, grounded in people's experiences. The next argument, the third major argument, why research with children as theologians is important, is based on this more inductive view on theology (see also Müller 2019).

\section{Ethnography with children as theology and pastoral care}

Empirical research with children is not only relevant for theology or for the study of lived religion (see Section 2.2), or for making sure that children's voices are heard (within theology, within pastoral practices and educational theories), but the research itself can also be considered as a form of theology or even as a form of pastoral care. Here, I refer to another major discourse within contemporary practical theology (for an overview of various approaches to empirical methods in practical theology, see Osmer 2014). I refer to what is called 'theological ethnography' by Wigg-Stevenson (2014) 'ethnographic theology', 'ethnography as theology and ethics' by Sharen and Vigen (2011), or 'ethnography as a pastoral practice' by Moschella (2008). Although all these authors have slightly different views on the relation between theology and ethnography, they all consider their empirical work as 'theological' as such. Here, the interpretation of theology is more stretched than in most classical views.

Moschella (2008) explains how doing ethnographic work can also function as a form of pastoral care.

When Kantembe (2015), from Malawi, was playing with children in Malawian hospitals and interviewed them about their spirituality, this was not only good for his dissertation research but also offered a unique opportunity to the children to speak with someone. Especially in this context, Kantembe (2015) experienced that there were many preachers coming to the hospitals to teach prayers to children and to preach them, but only seldom did the children receive pastoral conversations about their own lives and spirituality. What Kantembe (2015) offered them in the context of his research was valuable as such, relying on his training as a priest, with experience in hospital chaplaincy in Malawi and well informed about recent developments in childhood studies and theology.

One can, however, critically ask whether it is true that children also gain by the research and that with children, empirical researchers act as theologians and pastoral caregivers even whilst doing the research. I used to discuss the chapter of Browning (2011), part of Scharen and Vigen's (2011) book, on 'Beliefs and Moral Formation of Street Children' with my students. She did ethnographic work with street children in Kenya, and asked them about their spirituality. The children were particularly eager to receive some gifts (milk) from researchers. Many of my students wondered whether this kind of research is not a form of instrumentalisation of children, using them only for the researcher's stake. Do they really profit from the research? Or are they only used to gather interesting data that would bring forward good articles and maybe academic promotions or profit for the researchers? Is this research about spirituality really the most urgent in this particular context? It is difficult to evaluate this particular case and piece of research, but it brings us to an important ethical caveat in doing research with children. It is extremely important for researchers to ask the question, how children gain from the research, and how it should not be a burden for 
them. In the near future, I am setting up research with children in a very poor neighbourhood in Manila, in the Philippines. The major aim is to help them to express their own ideas, their views, their sufferings and strengths. The danger is, of course, that the interviews may make life more difficult, and that we do not really help the children, their families or the local parish to speak about the needs, opportunities and strengths in their lives and community. We will try to avoid that by working closely together with local communities, professors and parish leaders, and using an approach based on 'appreciative inquiry', which helps the local community, including the children, to express together what is valuable for them and to envision the future. We will enable them to reflect on what they can create themselves to support the community and especially also children's lives and spiritualities. But it is very important to be aware of the risks of instrumentalisation.

Ethical committees, which have to acknowledge empirical research in academic contexts, are particularly worried about research with specific groups of vulnerable people. Children classically belong to that kind of group, as well as persons with disabilities, dementia, patients and others. The German practical theologian Krause (2019) argues, however, that vulnerabilities should not in the first place be considered as characteristics of individual persons, but are the result of a 'framing activity'. It depends on the way in which we consider the persons and their activities whether these persons are particularly vulnerable, Krause (2019) explains in reference to people with dementia in a liturgical setting. Everybody is confronted with vulnerabilities, but this is not a static essentialistic characteristic which could exclude people from research, Krause (2019) argues. Speaking about vulnerabilities (in plural) as 'constructed' and 'framed' helps us to consider children as whole persons, with their strengths as well. It does not free us from being cautious in the way persons, especially children, are treated in empirical research. In the next part of this article, good ethical and methodological practices for doing research with children are summarised.

\section{Good practices for research with children as theologians: Ethical and methodological considerations}

Most handbooks for empirical research dedicate a chapter to 'research ethics', and there are various specialised works on research ethics with children. Most universities also ask their researchers to ask for ethical clearance when they start empirical research. These forms and guidelines help researchers and students to reflect on most aspects of the research. However, ethical considerations for research with children do not stop when ethical clearance is given by an ethical committee (Zimmerman 2018). In this section, some good practices combined with examples about research with children 'as theologians' are described in short.

It is important to reflect extensively about the research design. Which steps are to be taken, which methods are to be chosen for gathering empirical data, and also for analysis? Various options are possible: Mostly research with children about theological topics is based on semi-structured interviews, which could be carried out in a one by one setting, or in a group. When these interviews take place in a group context, we speak about focus groups (see, e.g., Kammeyer 2009).

From an ethical perspective, it is important to make sure that children feel safe enough to speak. Sometimes an interview with a few others present might be important for the child or adolescent, as Casteel experienced when interviewing adolescents who recently migrated from their country and arrived in Greece (part of $\mathrm{PhD}$ research). A few of the adolescents wanted to be interviewed with other persons present. In such a situation, it is important to respect the feelings and needs of those who are interviewed, even if classical research protocols would tell researchers to avoid this, as people might give socially acceptable answers.

Sometimes a focus group is interesting when the researcher might elicit various views, within a short period. This worked very well in the research of Jeroen Hendrickx who interviewed a small group of adolescents after a Godly Play experience (see Dillen \& Hendrickx 2018). When one adolescent gave his or her view on what happened, some were supporting that viewpoint, others explained that they experienced it in a different way. This focus group method helped the researcher to grasp various opinions and to gain a deeper understanding of the various viewpoints, as the various ways of expressing them helped the adolescents to express adequately what they were thinking. In many other situations, one-to-one interviews might be preferred. Most relevant is that the researcher learns to know the children, and does not function as a total stranger when he or she starts the interviews. Trust is a very important aspect, not only because the validity of the answers is increased when children speak spontaneously and do not have to please the researcher, but also because the combination of a research context and the adult researcher introduces power differences. In order to deal in an adequate way with the unequal power balance, it is important that the researcher and the child(ren) learn to know each other by doing activities together (e.g. being present in a classroom, playing with the children) before the start of actual research. A period of participant observation might also be important in the research design. Research with children asks for flexibility and research designs that are flexible. Therefore, semi-structured interviews, where the interviewers might add or skip questions and change the order of the questions, are preferred over structured interviews with a fixed order of questions.

Sometimes it is preferable to interview persons who know much about a specific group of children instead of interviewing the children themselves. This was, for example, the case when Julia Day wanted to know more about ways in which Muslim children speak or don't speak with caregivers about experiences of sexual abuse (Day \& Dillen 2016). It would have been very difficult to find Muslim children who were victims of sexual abuse and who would agree to an interview on this topic, especially as the hypothesis of the research was that this topic is a real taboo amongst Muslim children and in Muslim communities. Further on, it would raise too many ethical 
issues if the children had to speak about sexual abuse again, only for the sake of this particular research. In that case, we have chosen to interview caregivers, as they see many children and might have an overview because of their experiences with various children and many years of experience. Here, the direct voices of the children are not heard, but the children find a place in the research through the voices of caregivers.

Of course, quantitative research designs are also possible, or mixed method approaches (e.g. online surveys and interviews afterwards). Most aspects are valuable in this situation as well, but here the focus is on qualitative research as this is most common. Often, children are asked to draw something, or they are given another creative task. This might help them to think in a personal way, to be creative and find pleasure in the task, and it might give the interviewer something concrete to talk about. When thinking about the research design it is also important to think about methods of analysis (e.g. thematic content analysis, grounded theory etc.).

During the first process of data gathering and during the analysis of the data, there is always the risk of over interpreting what children make or say. Researchers might have their own presumptions about what children think. If possible, good practices include checking interpretations with those whose ideas and practices are the object of research. This is sometimes called 'member-check'. When children are called theologians, one would expect this basis form of considering children as co-researchers who help to interpret the scientific data. Here we encounter one of the complexities in 'doing research with children as theologians'. The term 'theologians' is first of all used in line with emancipatory theologies and tries to value children's contributions. Secondly, it might also refer to children who are not only objects but also subjects of the research, being involved in the process of the research. Discussing research results with children might be a small possible step in this line if the results are presented in an accessible way.

Very important for every form of empirical research is 'informed consent', as this protects the value of 'autonomy'. Children and their parents must have the right not to participate, and even to stop their participation in the middle of the research. An informed consent form must be signed by the parents or guardians, and preferably also by the child. But of course, the researcher should also explain everything that is on the information sheet about the aims of the research, about anonymity, about possible publications afterwards, etc. It is important that as far as possible this is expressed in the mother tongue of the child/parents/guardians. When a very diverse group of children is interviewed, the language cannot always be the mother tongue. Very important is that the researcher already asks permission for using the data in publications.

In the information sheet and the informed consent document that is signed by the researcher, the parent(s)/guardian(s) and the child, the question of anonymity should be explained. This means that pseudonyms will be used, that only short quotes will be used in publications and that full interviews will not be distributed, printed or be made available online. It also means that details which make the child recognisable are not to be given. Sometimes researchers have to find a balance between giving relevant information in order to show the reader that the group of participants is diverse or adequate for the research aims and between safeguarding the anonymity of the child. For instance, when children from specific classes in a particular school are interviewed, it might be wise not to mention the class and the school, but it might be good to indicate how many boys and how many girls are interviewed. Anonymity is important in order to protect the children who do not know who might use their quotes later on, and the exact names are seldom relevant in answering the research question. Important is also that researchers think about a 'data management plan'. This means they have to indicate when the audio-files are to be deleted (usually after transcription, as audio-files do not protect the anonymity of the child), where the full transcripts are to be stored (usually only on one computer), and where the codes, which might help the researcher to link the pseudonymised data with personal data (such as address or phone number) are to be stored (preferably in another place, on another external hard drive or even digital vault than where the data itself are stored). The information sheet and informed consent form should also indicate who has access to the data (co-researchers, colleagues, supervisors, etc.).

It is important that researchers indicate where children could find support after the research. Firstly, they should be available themselves and indicate how they could be reached for further questions. Talking about religion and spirituality might be very powerful and important for many children, but sometimes they want to continue the dialogue about it or they might struggle with some aspects that were discussed during the research. It is important that the researcher provides a sheet of information with other contact person's details before the interview starts. This could be a general hotline, a chaplain or pastor related to a local church, a teacher, or other persons in various positions. If possible, the researcher might also ensure that during a next meeting of the group of children participating in the research, the regular teacher, catechist, pastor, religious leader, etc. comes back to the research and if needed discusses some elements. Research is always influencing children and does not have to be a 'stand-alone activity'.

It is very important that children have feedback about the research in a way they understand. The researcher might come back to present results, or even to discuss some of the outcomes of the research and integrate the children's comments in a later stage as well. Or information can be made available in a written or online form, adapted to what children can understand. This is important, as during the first process of data gathering and during the analysis of the data there is always the risk of overinterpreting what children make or say. Researchers might have their own presumptions about what children think. In general, ethical practices of empirical research include checking interpretations with those whose ideas and practices are the object of research. This is also called 'member-check'. When children are 
called theologians, one could expect this limited form of considering children as co-researchers who help to interpret the scientific data.

At this point, we encounter one of the complexities in 'doing research with children as theologians'. The term theologians is, first of all, as I did above, used in line with emancipatory theologies and tries to value children's contributions. It might also refer to children who are not only objects but also subjects of the research, being involved in the process of the research. Discussing research results with children might be a small possible step in this line. However, although both interpretations of the term theologians are meant to empower children, to take them seriously and to give them a voice, some harm might be done to them as well by calling them theologians. The practical theologian Courney T. Goto (2018:178-180) speaks about 'the harm of epistemic violence' in relation to research with minority groups. She does not speak about children, but a few of the insights she developed, based on a decolonial way of thinking, might help us to see the ambiguity of 'doing research with children as theologians'.

Goto (2018:178-179) describes epistemic violence as the harm done to an individual when her understanding of her reality is ignored, obscured, and overridden by another person (or persons) who in words and actions redefine(s) that reality'. She explains how 'epistemic violence' happens when non-experts, non-academics and/or local persons are forced to use expert language such as 'theology' or calling them 'theologians'. Their own 'native' language, their common way of talking, sharing insights and practicing, might not be fully heard but might be forced into academic language that overlooks the own meaning of the group that is researched. Many might welcome this language, called 'trade language' by Goto (2018:179), in reference to Duek and Reimer (2009). This can be explained by processes of 'mimicry', which is trying to copy the oppressor. This 'trade language' of empirical methodology, and also the use of the term 'theologians' for those whose insights and practices are researched, might be experienced as a form of empowering, due to the process of 'mimicry', Goto explained. However, it is important to recognise the complexity of the processes of 'mimicry' and 'epistemic violence', even if this is not experienced as intentional harm done by those in power and by the reactions of those in minority groups or in depencency situations.

It is clear that the danger of 'epistemic violence' might also apply to situations of research with children as theologians, although the research with children is often set up as a way to avoid epistemic violence, namely, to avoid that children's own voices are not heard and that adults only talk about children, but never listen to them. As above, applying an insight from the perspective of postcolonial and decolonial studies to research practices is not fully evident, as the relation with children and adults is to a certain degree always asymmetrical and children learn and grow by copying adults' behaviour and ideas. Nevertheless, the discussion about the danger of epistemic violence helps us to name possible dangers in research with children. Children's own views on religion and spirituality might be interpreted as more or less in line with adults' ways of thinking, e.g. when researchers speak about measuring children's postcritical belief in line with adults postcritical way of thinking (see the quantitative empirical research of Pollefeyt, Hutsebaut and others as published in Henckens et al. 2011). This interpretation might empower children and consider them as more than 'not-yetadults', but their own way of thinking and their own style of expressing thoughts might be overlooked. Sometimes, only expressions and ways of thinking that fit into specific educational models are considered in research and practices. In situations of qualitative empirical research, children might be forced into situations or practices which are not common to them in order to start 'theologising'. Also, discussing research results with children might be considered as a way to import specific jargon to children.

In order to avoid the 'epistemic violence' as much as possible, it is good that researchers learn to know the life world of children as much as possible, as described above. Checking whether academic researchers and a group of children really understand each other and making presuppositions of researchers more explicit and checked is also important, even if sometimes ambiguous, because this might also not be familiar to children and thus impose a form of 'trade language' to them. Goto (2018:185) explains how 'building relationships', 'fostering communication' and 'mutual regard' are key-elements in trying to avoid possible harm coming with epistemic violence. Specifically for children, this means intergenerational practices and forms of learning are relevant, not only as such, but also as a practice within the context of research. In addition, it is relevant to see that intergenerational religious activities have not been studied very often within the context of empirical or practical theology. Ethnographic research (especially participant observation) on specific intergenerational practices could also show how children not only receive but also give to adults, by considering them as 'theologians' in a way that is familiar to them and is less focused on imposing specific research constraints.

Avoiding all forms of 'epistemic harm' is nevertheless very complex. However, taking these ambiguities seriously in the reflexivity of the researcher and trying to avoid 'epistemic violence' in the design of a study is a minimum requirement. In reflecting on good ethical practices, most people will agree that all forms of harm should be avoided, as much as possible - even if many of them would never have thought about something such as 'epistemic violence'. But ethical practice is more than avoiding harm; it is also stimulating positive things and contributing to the 'common good'. Importantly, this research is, in general, increasing justice in society, as well as supporting sustainability and gender equality. It is not easy to answer how every specific form of empirical research fits into these general criteria, but they might be helpful as general guidelines. In this way, it is clear that ethical research is more than following technical guidelines about specific issues such as informed consent. 


\section{Conclusion}

There are more good practices to describe, and more reasons to give why empirical research with children as theologians is important. This article is meant to stimulate reflection amongst researchers and to increase awareness about various aspects of research with children. This is important for the children themselves, for the scientific community and for each researcher who would grow in reflexivity and recognise his or her own position and influence in the research. It is hoped that various groups of children themselves might eventually profit from this academic endeavour.

\section{Acknowledgements}

The author thanks the FWO and the KU Leuven for their research grants that made this research possible. The author also thanks Amy Casteel for her support in the editing of this article.

\section{Competing interests}

The author declares that no financial or personal relationships are involved that may have inappropriately influenced the writing of this article.

\section{Author's contributions}

A.D. is the sole contributor to this research article.

\section{Ethical considerations}

This article followed all ethical standards for carrying out research without direct contact with human or animal subjects.

\section{Funding information}

Funding for this study was provided by the FWO and the KU Leuven through research grants.

\section{Data availability statement}

Data sharing is not applicable to this article as no new data were created or analysed in this study.

\section{Disclaimer}

The views and opinions expressed in this article are those of the author and do not necessarily reflect the official policy or position of any affiliated agency of the author.

\section{References}

Astley, J., 2013, Exploring ordinary theology. Everyday Christian believing and the church, Ashgate, Farnham.

Bales, S.R., 2005, When I was a child: Children's interpretations of first communion, University of North Carolina Press, Chapel Hill, NC.

Browning, M., 2011, 'Theology and morality on the streets: An examination of the beliefs and moral formation of street children in light of Christianity and African traditional religions', in C. Scharen \& A.M. Vigen (eds.), Ethnography as Christian theology and ethics, pp.142-160, Bloomsbury, New York.

Cameron, H., Bhatti, D., Duce, C., Watkins, C. \& Sweeney, J., 2010, Talking about God in practice. Theological action research and practical theology, SCM Press, London.
Casteel, A. \& Dillen, A., (in press), 'Crossing borders, changing faith', in O. Laarson (ed.) The impact of religion: Migration, integration and wellbeing, Routledge, London.

Day, J. \& Dillen, A., 2016, 'Drempels bij de communicatie over ervaringen van seksueel geweld. Visies van hulpverleners over kinderen in islamitische gezinnen', Religie en Samenleving 11(1), 31-56.

Dillen, A., 2016, 'Lived religion and the complex relations between practical theology, empirical theology, and religious studies', in C. Wolfteich \& A. Dillen (eds.), Catholic approaches in practical theology: International and interdisciplinary perspectives, pp. 15-30, Peeters, Leuven.

Dillen, A., 2017, 'Lived religion en theologie. Betekenissen en consequenties van de studie van geleefde religie', Tijdschrift voor Theologie 57(1), 60-78.

Dillen, A. \& Hendrickx, J., 2018, 'Experiences with Godly play in Flanders. Research with secondary school adolescents', in M. Steinhäuser \& R. Oystese (eds.), Godly play. European perspectives on practice and research. Gott im Spiel. Europäische Perspektiven auf Praxis und Forschung, pp. 293-302, Waxmann, Münster.

Ganzevoort, R.R., 2013, Spelen met heilig vuur. Waarom de theologie haar claim op de waarheid moet opgeven, Ten Have, Kampen.

Grajczonek, J. \& Truasheim, M., 2015, 'Implementing Godly play in educational settings. A cautionary tale', British Journal of Religious Education 39(2), 172-186. https://doi.org/10.1080/01416200.2015.1110112

Hay, D. \& Nye, R., 2006, The spirit of the child, revised edn., Jessica Kingsley, London.

Hinsdale, M., 2001, “'Infinite openness to the infinite." Karl Rahner's contribution to modern Catholic thought on the child', in M. Bunge (ed.), The child in Christian thought, pp. 406-445, Eerdmans, Grand Rapids, MI.

Kammeyer, K., 2009, 'Lieber Gott, Amen!' Theologische und empirische studien zum Gebet im horizont theologischer Gespräche mit Vorschulkindern, Calwer Verlag, Stuttgart.

Kantembe, P., 2015, 'Nurturing children's spirituality in hospitals: Childhood studies and their theological implications for hospital Chaplaincy in Malawi', unpublished $\mathrm{PhD}$ dissertation, Faculty of Theology and Religious Studies, KU Leuven, Leuven.

Krause, K., 2019, 'People living with dementia celebrating Christian worship: Issues of vulnerability in ethnographical research', paper presented at the IAPT conference in Sao Leopoldo, Brazil ,04-08 April 2019.

McGuire, M., 2008, Lived religion. Faith and practice in everyday life, Oxford University Press, Oxford.

Mette, N., 2005, Einführung in die katholische praktische theologie, Wissenschaftliche Buchgesellschaft, Darmstadt.

Miller-McLemore, B., 2003, Let the children come. Reimagining childhood from a Christian perspective, Jossey-Bass, San Francisco, CA.

Moschella, M.C., 2008, Ethnography as a pastoral practice. An introduction, The Pilgrim Press, Cleveland, $\mathrm{OH}$.

Müller, P., 2007, 'Godly play - Hermeneutisch, exegetisch und religionspädagogisch betrachtet', in A.A. Bucher, G. Büttner, P. Freudenberger-Lötz \& M. Schreiner (eds.), Man kann Gott alles erzählen, auch kleine Geheimnisse. Kinder erfahren und gestalten Spiritualität (Jahrbuch für Kindertheologie), pp. 91-102, Calwer, Stuttgart.

Müller, S., 2019, Gelebte theologie impulse für eine pastoraltheologie des empowerment, Theologischer Verlag, Zürich.

Nikitaki, S., 2018, 'The place of nonbelief studies in the academic study of religion: Issues and insights', Paper presented at the Formatting Nonreligion in Late Modern Societies: Institutional and Legal Perspectives, University of Oslo, Norway, 26-27 September, 2018.

Office of the United Nations High Commissioner for Human Rights (OHCHR), 1989, Convention on the Rights of the Child, viewed 30 November 2019, from https://www. ohchr.org/en/professionalinterest/pages/crc.aspx.

Osmer, R., 2014, 'Empirical practical theology', in K. Cahalan \& G. Mikoski (eds.) Opening the field of practical theology: An introduction, pp. 61-78, Rowman \& Littlefield, Lanham, MD.

Rahner, K., 1966, Gedanken zu einer Theologie der Kindheit, in Id., Schriften zur theologie, band VII. Zur Theologie des geistlichen Lebens, pp. 313-329, Benzinger, Einsiedeln Zürich Keulen.

Scharen, C. \& Vigen, A.M. (eds.), 2011, Ethnography as Christian theology and ethics, Bloomsbury, New York.

Schweitzer, F., 2011, Kindertheologie und elementarisierung: Wie religiöses Lernen mit Kindern, Gütersloher Verlagshaus, Güthersloh.

Slee, N., 2004, Women's faith development: Patterns and processes, p. 44, Ashgate, Farnham.

Slee, N., Porter, F. \& Phillips, A. (eds.), 2013, The faith lives of women and girls, Ashgate, Farnham.

Slee, N., Porter, F. \& Phillips, A. (eds.), 2018, Researching female faith: Qualitative research methods, Routledge, London.

Wall, J., 2004, 'Let the little children come. Child rearing as challenge to contemporary Christian ethics', Horizons 31(1), 64-87. https://doi.org/10.1017/\$0360966900001079

Wall, J., 2010, Ethics in light of childhood, Georgetown University Press, Washington, DC.

Wigg-Stevenson, N., 2014, Ethnographic theology: An inquiry into the production of theological knowledge, Palgrave, New York.

Zimmermann, M., 2015, 'What is children's theology? Children's theology as theological competence: Development, differentiation, methods', HTS Teologiese Studies/ Theological Studies 71(3), Art. \#2848, 6. https://doi.org/10.4102/hts.v71i3.2848

Zimmermann, M., 2018, 'Respecting boundaries. Ethical standards in theological research involving children', in M. Steinhäuser \& R. Oystese (eds.), Godly play. European perspectives on practice and research. Gott im Spiel. Europäische Perspektiven auf Praxis und Forschung, pp. 248-265, Waxmann, Münster. 